\title{
INTERACTION EFFECT OF SUSTAINABILITY REPORTING AND ENTERPRISE RISK MANAGEMENT ON BUSINESS PERFORMANCE
}

\author{
Michael Goman', Fransiskus E. Daromes ${ }^{2}$, Paulus Tangke ${ }^{3}$ \\ 1,2,3 Departemen Akuntansi, Universitas Atma Jaya Makassar, Indonesia \\ Corresponding Author: fedaromes@gmail.com
}

\begin{abstract}
This study provides empirical evidence of the interaction of sustainability reporting and Enterprise risk management on business performance. A number of previous literatures have found a significant positive effect of ERM implementation on overall business performance, however, the number of studies investigating the interaction of sustainability reporting and ERM is still limited. We build this research model based on modern portfolio theory and stakeholder theory. Data testing was carried out using the moderation regression method in examining the three variable relationships above. The results showed that there was a significant positive effect of ERM on business performance as measured using EVA. Meanwhile, sustainability reporting, although able to strengthen the coefficient of determination relationship between ERM and EVA, does not have a significant moderating effect on the relationship between the two variables.
\end{abstract}

Keywords: ERM, EVA, sustainability reporting

\begin{abstract}
Abstrak
Studi ini memberikan bukti empiris tentang interaksi pelaporan keberlanjutan dan manajemen risiko perusahaan terhadap kinerja bisnis. Sejumlah literatur sebelumnya telah menemukan efek positif yang signifikan dari implementasi ERM pada kinerja bisnis secara keseluruhan, namun jumlah penelitian yang menyelidiki interaksi pelaporan keberlanjutan dan ERM masih terbatas. Kami membangun model penelitian ini berdasarkan teori portofolio modern dan teori pemangku kepentingan. Pengujian data dilakukan dengan menggunakan metode regresi moderasi dalam menguji ketiga hubungan variabel di atas. Hasil penelitian menunjukkan bahwa terdapat pengaruh positif yang signifikan dari ERM terhadap kinerja bisnis yang diukur dengan EVA. Sementara itu, sustainability reporting, meskipun mampu memperkuat hubungan koefisien determinasi antara ERM dan EVA, tidak memiliki pengaruh moderasi yang signifikan terhadap hubungan kedua variabel tersebut.
\end{abstract}

Kata kunci: ERM, EVA, sustainability reporting

\section{Introduction}

\section{Enterprise risk management}

(ERM) is a framework which can be implemented by a firm's management in an effort to address inherent uncertainty within every business
Article History

Received : 2021-04-28

Revised : :2021-05-30

Accepted : 2021-07-29

\section{c) (1) (0)}

This is an open access article under the CC-BYSA License 
activity. Implementation of ERM is useful in minimizing undesirable results within each activity and projects, which indirectly have positive impacts towards business performance. A number of past literatures have investigated the impact of ERM towards business performance (Florio \& Leoni, 2017; Hoyt \& Liedenberg, 2011; Waweru \& Kisaka, 2012). The conclusion of these research are still ambiguous, since there're also a number of research which found no concrete relations between ERM and business performance (Tahir \& Razali, 2011; Agustina \& Baroroh, 2016; McShane et al., 2011). Within this research, we intend to add sustainability reporting as a moderating variable, in an effort to better explain and enhance the relationship between ERM as independent variable and business performance as dependent variable. Sustainability reporting is chosen as moderating variable since the report contains and explains a number of internal and external factors of organization which are expected to enhance ERM ability in explaining changes within business performance.

A number of past literatures has investigated relationship between ERM and business performance. Nocco and Stulz (2006), argued that ERM is intended to increase shareholder's value through the increase of risk and return trade-off on various business projects. Florio and Leoni (2017) have investigated past literatures on risk management, and found relationship between risk management and firm value. Hoyt and Liebenberg (2011) have studied and compare overall value of insurance company which use and doesn't use ERM, and found significant effect of ERM on firm value. Lai et al. (2011) argued that implementation of ERM in organization can results in shareholder value creation. Lai develops a model that describe causal relation between ERM implementation and increase of shareholder value. ERM can gives company advantage, whether tangible or intangible, which could lower cost 
of capital and increase business performance.

Waweru and Kisaka (2012) investigate whether ERM positively or negatively affect business performance. They found ERM implementation not as a form of legal compliance, but business strategy initiative. The result of their research implies positive relationship between both variables.

Not all research shows significant and positive result on the relationship of ERM and business performance. A number of them also shows ambiguous and inconclusive results. Tahir and Razali in their 2011 research show that ERM positively affects business performance, measured in Tobin's Q, however not in a significant degree. They argued, difference between their research and past literature shows that ERM implementation in Malaysia are still at an early stage, and firms knowledge on ERM are still limited. Agustina and Baroroh (2016) also found no significant relation between ERM and firm performance, nor profitability.

McShane et al.

emphasize how research on ERM and business performance shows inconclusive and mixed results. Using S\&P's ERM rating, McShane et al. found evidence of positive relation between traditional risk management capacity with firm value, however, they didnot found any firm value increase correlated with high ERM. McShane also argues, one of the limitations within ERM research is unavailability of appropriate proxy to reflect ERM implementation level and capabilities.

\section{Literature review}

\subsection{Stakeholder Theory}

Stakeholder theory explains about constituency or entity outside of business, which is affected by the business itself. Stakeholder includes employee, supplier, local community, creditor, etc. In 1984, Freeman argued that firm should create value, not merely for shareholders, but to stakeholders too. Freeman focused 
this theory on business ethics and management to explain important moral and values in managing a business or organizations.

All stakeholders wished for organization to disclose its activities, and they have the rights to obtain related information on how firm's activity will also affect their activities, even if they have no direct roles in the organizations. The fulfillment of stakeholder's expectations regarding organizations disclosure could then potentially increase goodwill and the image of organization, thereby allowing it to maintain its status and reputation within society, allowing increase in firm value.

Disclosure related to economy, environment, and social aspects determines the success of organization in fulfilling its responsibility, and that organization's activities have been in accordance with community value and environment. In the context of shareholder theory, it has been argued that effective and rigorous implementation of corporate risk management practice and sustainability reporting could increase economic value of a company (Shad et al., 2019).

\subsection{Modern Portfolio Theory}

Markowitz (1952) is the first person who introduced modern portfolio theory (MPT). MPT was first explained in 1952, as an investment theory which emphasize risk and return trade-off. MPT emphasize management's responsibility in selecting which investment can give higher return. The diversification of investment into a number of assets has a collectively smaller risk compared to investment into a single, specific asset.

MPT has an implication toward risk minimization, through investment in portfolio which has lower overall risk. This theory argues that a risk concept which is specifically related to business is not connected with shareholder's value, since the shareholders themselves are 
only equipped with two tools, which are asset diversification and allocation to minimize overall risk.

Markowitz suggest company to implement risk management since shareholder are not the only stakeholder of an organization. Risk management are also useful to increase a company's financial performance and sustainable development

\subsection{Enterprise Risk Management}

Since mid-1990s, risk management has emerged as a concept and function of management in corporates. Enterprise risk management is a systematic and integrated approach toward management of all risk faced by the organization (Dickinson, 2001; Daromes, et al., 2020). There is still shortage on studies exploring effectivity and advantage of ERM. However, as a potential concept that could improve the flaws in traditional risk management, ERM studies slowly increased in an effort to find better ways to assess and manage risk.
One of many ways in measuring implementation of ERM in a corporate setting has been introduced by Gordon et al. (2009), named Enterprise Risk Management Index (ERMI). This index is based on four main objectives of ERM within COSO. ERMI based its measurement from ERM abilities to fulfill its role, related to strategy, operation, reporting, and compliance.

\subsection{Business Performance}

Business performance can be valued using primary or secondary measure. Primary measure, or perceived measure, also known as subjective measure, are measurement achieved from survey and questionnaire (Selvarajan et al., 2007). Secondary measure, or objective measure, use secondary data such as financial data to measure firm performance. According to Richard et al. (2009), this secondary measure are divided into 3:

1. Accounting measure, such as sales percentage, profit, ROA, ROE, and ROI 
2. Market measure, such as number of sales and market shares

3. Hybrid measure, such as shareholder's return, and Economic Value Added (EVA)

EVA is a measurement of currency surplus, created by an investment or investment portfolio. Use of EVA represents an effort to measure whether management of an entity has utilizes their available resource to create or diminish firm's value.

\subsection{Sustainability Reporting}

World Commission on Environment and Development Report (1987), also known as Brundtland Report, has defined sustainability development as "Development which meets the needs of the present without compromising the ability of future generations to meet their own needs". Sustainability concept can be classified into three categories, economic, social, and environmental sustainability. These three dimensions are commonly known as triple bottom line (3BL), first mentioned by J. Elkington (1994).

A company focused on sustainability has to ensure their business can manage risk while also fulfilling stakeholder's expectations. Not all companies prepare and publish their sustainability reporting, since it's still deemed voluntary. Hamudiana and Achmad (2017) argued, it could be hypothesized that there are factors pushin a firm to publish such report. Each company which focused on different industries, will also have pressures from different stakeholders. As an example, a company in oil and gas industry will find themselves under stricter monitoring from stakeholders according with their risk management. Risks included within oil and gas industry include regulation, social and environmental, health, and workplace safety issues alongside the common operational business risk. Management needs 
bigger efforts to maintain overall performance within a dynamic and risky environment.

\subsection{Theoretical Framework}

ERM in a business covers methods and process which are used to assess and mitigate risk. ERM prepares a conceptual framework, covering identification of cases or events relevant to organizations objective, which could either be threat or opportunity, assessing the probability to happen and potential impact, and also preparing strategies for responding. By proactively dealing with potential risk, organization could protect its shareholder's value, either economically from shareholder's side, or environmentally or socially from the rest of stakeholders.

From past literature, it could be assumed that relationship between ERM and business performance are still inconclusive. Results of a number of studies shows either positive and significant, or insignificant. Based on this premise, this research aims to introduce sustainability reporting as a moderating variable into the existing relationship of ERM toward business performance.

The size of ERM's impact as independent variable on business performance can be enhanced by introducing a number of company's internal and/or external factors. This could include strategy and characteristics of organizations, which could show firm's ability in dealing with internal risk, and also increasing its business performance. Meanwhile, other factors such as environmental change and social welfare could also affect organizations in reaching its strategic objective or long terms goals.

In line with above argument, we decided to use sustainability reporting as moderating variable. Within sustainability report, we can commonly find information related to organization's profile and management (internal factors), and also projects and activities toward 
realizing social and environmental welfare (external factors). Within sustainability report, are also covered discussion on either internal and external factor which can support ERM in increasing business performance.

We use modern portfolio theory as basis for ERM and business performance relationships. This investment theory emphasizes on the trade-off between risk and return. Each organization has different risk exposure level, therefore, in choosing an investment, any potential risk must also be considered alongside potential return. In this context ERM can indicate, even if the return is not exceptionally profitable, but can still be steady and sustainable in the long run. Risk-aware investors surely will seek indicators of organization's risk, one of which can be find through implementation of ERM.

We use stakeholder theory to explain the moderating role of sustainability reporting. According to this theory, management has a responsibility to create value for stakeholders. Freeman (1984) emphasize morals and values needed to achieve social and economic responsibility in organization. Sustainability reporting and ERM implementation are done as an effort to fulfill this responsibility toward stakeholders, whether internal or external. Figure 1 shows the theoretical framework we use as the base of this research. 


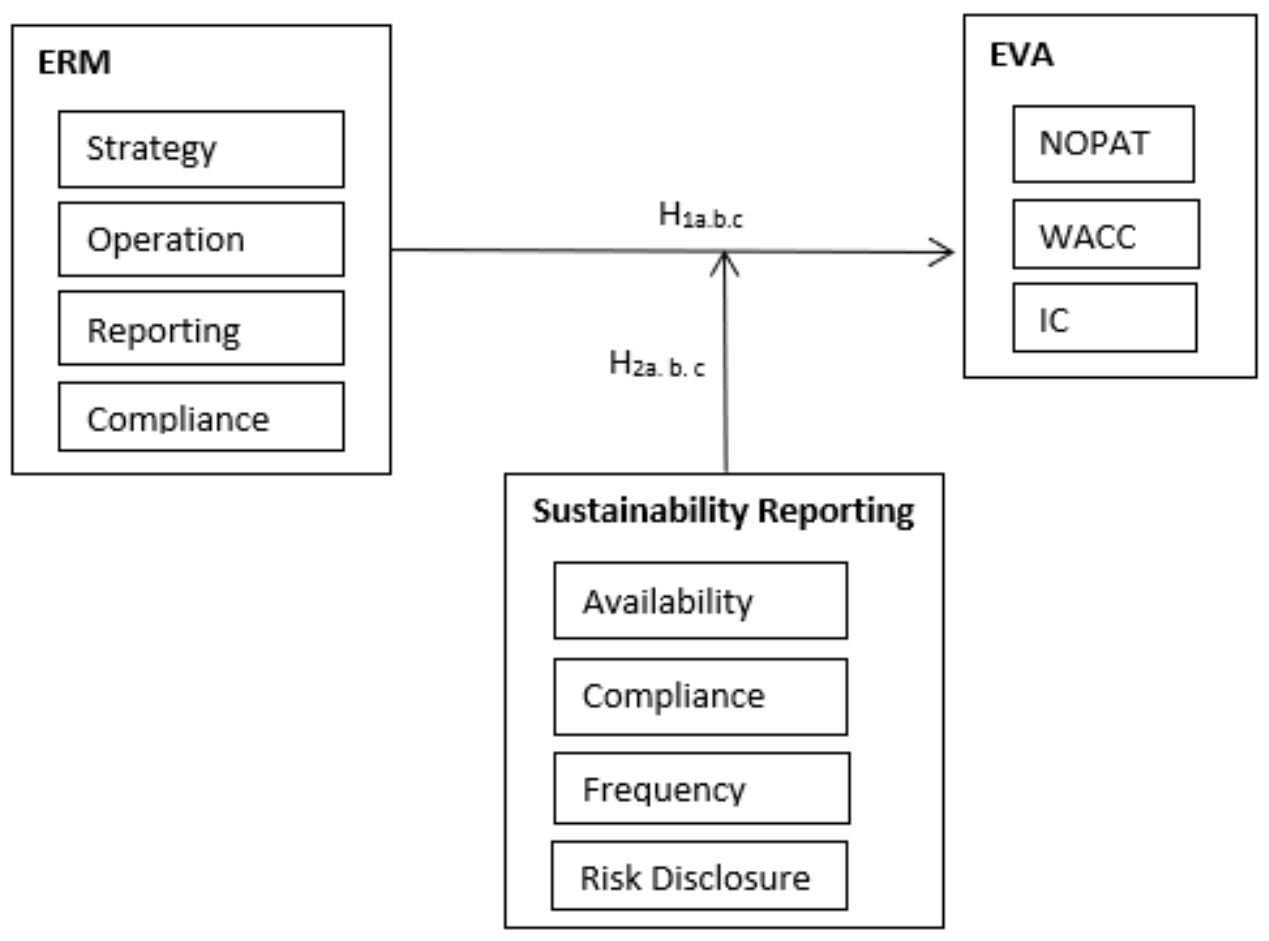

Figure 1

Theoretical Framework

Source: developed in research (2021)

\subsection{Hypothesis Development}

\subsubsection{Implementation ERM and EVA}

Main aspect for ERM to become primary consideration to increase business performance is its ability to increase organization's awareness toward any kind of risk faced by the firm. Implementation of rigorous risk management system will give significant and positive impact to business performance. ERM is intended to create value toward shareholder by improving risk and return trade-off from various company projects, which could give competitive advantage and business performance increase.

H1a: Implementation of ERM will have positive impact toward NOPAT

Risk monitoring and disclosure can decrease operational risk and support business to focus their resource on business activities and firm value 
creation. In accord with this, ERM can decrease fluctuation from operating income. Increase in sales and decrease in cost of goods can then improve net operating income after tax (NOPAT).

H1b: ERM Implementation will have negative impact toward WACC

H1c: ERM implementation will have positive impact toward IC

\subsubsection{Sustainability Reporting moderates the relationship between ERM and EVA}

Relationship between ERM and business performance can be enhanced through sustainability reporting, which disclose economic, social, and environmental interests (3BL) to all stakeholders. Sustainability concept can build goodwill in the eyes of stakeholders, which can improve a more positive decision making and better implementation of risk management. Combination of internal and external factors of organization disclosed within sustainability report can induce a positive synergistic impact, which are greater compared to the sum of its separate effects.
H2a: Sustainability Reporting moderates the relationship between ERM and NOPAT

Sustainability reporting disclosure reflects a good corporate image, and can motivates stakeholder to maintain and improve that image. Monitoring and risk disclosure reflected in sustainability report can also increase corporate charms in investor and consumers, which could potentially increase operating income.

H2b: Sustainability Reporting moderates the relationship between ERM and WACC

ERM's ability in lowering weighted average cost of capital can be enhaced with the introduction of sustainability reporting as moderating variable. Information related to company profile and strategy can improve creditor's perception on firm's credit rating, lower the expected rate of return from investor, and also cost of risk premium from debitor when issuing capital instruments such as shares and obligation. ERM implementation moderated with sustainability reporting can support credit rating and rate of 
return function as indicator of financial strength.

H2c: Sustainability Reporting moderates the relationship between ERM and IC

Shareholder's value is created when the actual return is higher than the expected return. Implementation of ERM communicated through sustainability reporting can optimize the trade-off between risk and return, enabling company to sustainably creates value.

\section{Research Methods}

In this study, the main research objects are financial report and sustainability report of corporate listed in Indonesia Stock Exchange (IDX), from the period of 2016 to 2018 . From each of this report, we'll extract data related to:

1. ERM implementation

2. Level of Sustainability Reporting

3. Firm Value (EVA), calculated from financial report items

Population of this study is listed companies within IDX, from 2016 to 2018. Data collection method is purposive sampling, and the data must fulfill the criteria listed below:
1. Company which implements ERM within its business activities

2. Company issues/issued sustainability reporting

3. Both financial reports and sustainability report are accessible to general public

Operational Definition and Variable Measurement

This study uses ERM measurement constructed by Gordon et al. (2009), named enterprise risk management index (ERMI). This index is based on ERM's four main objectives listed in COSO. Gordon et al. based their measurement on ERM's ability to fulfill its function in relation to strategy, operation, reporting, and compliance.

$$
\begin{aligned}
& \text { ERMI }=\sum_{k=1}^{n} \text { Strategy }_{k} \\
&+\sum_{k=1}^{n} \text { Operation }_{k} \\
&+\sum_{k=1}^{n} \text { Reporting }_{k} \\
&+\sum_{k=1}^{n} \text { Compliance }_{k}
\end{aligned}
$$

1. Measurement of Strategy are as follows. 


$$
\text { Strategy }=\frac{\text { Sales }_{i}-\mu_{\text {Sales }}}{\sigma_{\text {Sales }}}
$$

2. Measurement of operation efficiency are based on Kiymaz (2006), with the following equation

$$
\text { operation }=\frac{\text { Sales }}{\text { Total Assets }}
$$

3. Reporting reliability are measured using 3 components as follows

$$
\begin{aligned}
& \quad \text { Reporting } \\
& =\text { Material Weakness } \\
& + \text { Auditor Opinion } \\
& + \text { Restatement }
\end{aligned}
$$

4. Measurement for compliance are the proportion of audit cost to total asset

$$
\text { Compliance }=\frac{\text { Auditor Fees }}{\text { Total Assets }}
$$

We use the following subjective measurement criteria to measure the proxy value of sustainability reporting variable.

$$
\begin{aligned}
& \text { Sustainability Reporting } \\
& =\text { Availability + Compliance } \\
& + \text { Frequency } \\
& + \text { ERM(Risk Disclosure })
\end{aligned}
$$

1. Availability: measures availability of sustainability report on online network. Score of 0 indicates unavailability or inaccessibility of data, and 1 indicates availability and accessibility of data. Availability of sustainability reporting is the first step in ensuring there is communication of crucial information related to risk management and social and environmental responsibility to stakeholders. Availability of sustainability report also become evidence of corporate's concern that could increase image and also long term value

2. Compliance: compliance level towards GRI (Global Reporting Initiative) standards, measured from GRI-1 to GRI-4. Score of 0 indicates compliance to GRI, and score of 1 indicates noncompliance to GRI. GRI as a global organization for a long time has provide guidelines for communicating risk and organization's activities' impact toward social and environment. Firm's effort in communicating 
sustainability element within its activity can be reflected through its effort in complying to available guidelines. It can be argued that companies in comply with GRI standards are more comprehensive in disclosing and reflecting its concern in financial, social, and environmental sustainability.

3. Frequency: number of sustainability reports issued up to year 2019, calculated using zscore. The frequency of issuance reflects firm's consistency in disclosing its activities related to sustainability. Consistent frequency of disclosure each year reflects strong concern to communicate and face company's risk, which could give sense of security toward investors and stakeholders.

4. Risk disclosure: disclosure related to risk management, with score of 0 (barely mentioned) or 1 (in-depth disclosure). Here, we attempt to measure company's seriousness to communicate implementation of enterprise risk management. We argue that detailed communication of ERM implementation can also decrease investors and other stakeholders concern over potential risk faced by company.

The Equation of economic value added (EVA) used as measurement of business performance are as follows:

$\mathrm{EVA}=\mathrm{NOPAT}-($ WACC $\mathrm{x}$ IC $)$

Net operating profit after tax (NOPAT) are the profit earned from operational activity. Weighted average cost of capital, are calculated based on weighted average of interest rate after tax, and the rate of cost of equity, in proportion with debt and equity on company's capital structure. WACC formula are as follows:

WACC $=\left(m_{1} \times k_{\text {dafter tax }}\right)+$ $\left(m_{2} \times k_{e}\right)$

$m_{1}=$ proportion of cost of debt

$m_{2}=$ proportion of cost of equity

$k_{\text {d after } \operatorname{tax}}=$ cost of debt

$k_{e}=$ cost of equity

One way to measure cost of equity is as follows: 


$$
\begin{aligned}
& \text { Cost of Equity } \\
& =\frac{\text { Div. per Share }}{\text { Market Price per Share }} \\
& + \text { Growth rate of Div. (\%) }
\end{aligned}
$$

Linear Regression with Moderating Variables and Classical Assumption Tests

In this study, regression analysis is executed similar to simple regression, however with addition of one moderating variables (sustainability reporting). This moderating variable can be perceived as independent variable with ability to strengthen or weaken the relationship between the main independent variable and dependent variable.

Classical assumptions are included to know whether a deviation exist within regression models. Classical assumption tests also examine whether regression model have normal distribution.

\section{Results and discussion}

Table 1

Descriptive Statistics

\begin{tabular}{lllll}
\hline \multicolumn{1}{c}{$\mathbf{N = 2 0 8}$} & \multicolumn{1}{c}{ Minimum } & \multicolumn{1}{c}{ Maximum } & \multicolumn{1}{c}{ Mean } & \multicolumn{1}{c}{ Std. Deviation } \\
\hline ERMI & -2.72 & 7.97 & .5689 & 1.81735 \\
Sustainability Index & -1.41 & 5.05 & 1.9519 & 1.89232 \\
EVA & -104906395.60 & 25951949.23 & 18050.6090 & 12354769.69354 \\
NOPAT & -6483084.00 & 32701000.00 & 3306634.5026 & 6759107.19287 \\
WACC & -2.94 & 0.87 & 0.0194 & 0.33721 \\
IC & -5157160.00 & 733470351.00 & 47621867.0153 & 93115030.37624 \\
EVA_ASSET & -77.00 & 1.05 & 0.0249 & 0.19053 \\
Valid N & & & &
\end{tabular}

Source: SPSS 26.0 (2021)

EVA shows score for business performance. While three other variables below it, NOPAT, WACC, and IC shows descriptive statistics score from EVA components. EVA means show positive score at $18,050.6090$ with quite high deviation standard at $12,354,769.69$. this shows that each companies create varied surplus value after cost of debt and equity, where some company receive surplus, some reach breakeven, and the rest can't cover the cost of capital.

We also compare the score of EVA relative to net profit (NOPAT), as seen on the last row. Companies receive average surplus of $2.49 \%$ of the total 
cost of net profit. EVA surplus value are net operating profit after tax.

in the range of $-16.56 \%$ up to $21 \%$ from

Table 2

F tests Summary

\begin{tabular}{clll}
\hline $\begin{array}{c}\text { Regression } \\
\text { Model }\end{array}$ & \multicolumn{1}{c}{ Dependent Variable } & \multicolumn{1}{c}{ F } & Sig. \\
\hline \multirow{5}{*}{ Moderating } & EVA & 4.383 & .005 \\
& NOPAT & 18.991 & .000 \\
& WACC & .245 & .865 \\
& IC & 17.872 & .000 \\
\hline
\end{tabular}

Source: SPSS 26.0 (2021)

Above table shows the summary

of $\mathrm{F}$ tests for moderating regression with ERM as independent variable and sustainability reporting as moderating variable.

1. Moderating regression with EVA as dependent variable shows significance below 0.05, which shows all independent variables simultaneously affect EVA. Moderating regression model with EVA as dependent variable are therefore significant

2. Moderating regression with NOPAT as dependent variable shows significance below 0.05 , which shows that all independent variables simultaneously affect NOPAT. Moderating regression with NOPAT as dependent variable are therefore significant

3. Moderating regression with WACC as dependent variable shows significance above 0.05 , which shows that all independent variables are not simultaneously affecting WACC. Moderating regression with WACC as dependent variable are therefore not significant

4. Moderating regression with IC as dependent variable shows significance score below 0.05, which shows that all independent variables simultaneously affect IC. Regression moderation with IC as dependent variable are therefore significant

Table 3 
R Square Tests (EVA as dependent Variable)

\begin{tabular}{ccrrrr}
\hline $\begin{array}{c}\text { Regression } \\
\text { Model }\end{array}$ & $\mathrm{R}$ & R Square & Adj. R Square & $\begin{array}{c}\text { Std. Error of the } \\
\text { Estimate }\end{array}$ & $\begin{array}{l}\text { Durbin- } \\
\text { Watson }\end{array}$ \\
\hline Simple & $.213^{\mathrm{a}}$ & .045 & .041 & 12230171.41451 & .891 \\
\hline Moderating & $.247^{\mathrm{a}}$ & .061 & .047 & 12189369.10102 & .913 \\
\hline
\end{tabular}

Source: SPSS 26.0(2021)

Simple regression model with

ERM as independent variables and EVA as dependent variables has adjusted $r$ square value of 0.041 , therefore we can conclude that $4.1 \%$ of EVA score are affected by ERM, whereas the rest $95.9 \%$ are affected by external factors.
Moderating regression model with sustainability reporting as moderator shows adjusted $\mathrm{r}$ square with score of 0.047 , therefore we can conclude that $4.7 \%$ of EVA score is affected by ERM moderated by sustainability reporting, while $95.3 \%$ of EVA are affected by external factors.

Table 4

R Square Tests (EVA's Components as dependent Variable)

\begin{tabular}{ccc}
\hline \multirow{2}{*}{ Dependent Variable } & \multicolumn{2}{c}{ Adjusted R Square } \\
\cline { 2 - 3 } & Before Moderation & After Moderation \\
\hline NOPAT & 0.146 & 0.197 \\
WACC & -0.05 & -0.011 \\
IC & 0.163 & 0.208 \\
\hline
\end{tabular}

Source: SPSS 26. (2021)

Above table shows adjusted $r$ square values from both simple and moderating regression with EVA components as dependent variables. Adjusted $r$ square values of each dependent variables are strengthened by the addition of sustainability reporting as moderating variable.
From the table above, we conclude that addition of sustainability reporting as moderating variable can improve ERM ability to explain the variability of each of its dependent variable (EVA and its components), even if the increases are relatively small.

Table 5

t Tests Summary

\begin{tabular}{lccccc}
\hline Regression Model & $\begin{array}{c}\text { Dependent } \\
\text { Variable }\end{array}$ & Unstandardized Coefficients & $\begin{array}{c}\text { Standardized } \\
\text { Coefficients }\end{array}$ & $\mathbf{t}$ & Sig. \\
\hline
\end{tabular}




\begin{tabular}{lcccccc}
\hline & & B & Std. Error & Beta & & \\
\hline Simple & EVA & 1490360.191 & 478313.848 & .213 & 3.116 & .002 \\
Simple & NOPAT & 1479002.631 & 245438.134 & .388 & 6.026 & .000 \\
Simple & WACC & -.002 & .013 & -.011 & -.151 & .880 \\
Simple & IC & 21672021.900 & 3385432.663 & .408 & 6.402 & .000 \\
Moderating & EVA & 257250.960 & 264755.107 & .224 & .972 & .332 \\
Moderating & NOPAT & 153749.693 & 131326.086 & .246 & 1.171 & .243 \\
Moderating & WACC & .006 & .007 & .195 & .822 & .412 \\
Moderating & IC & 939946.335 & 1840787.183 & .108 & .511 & .610 \\
Source: SPSS $26.0(2021)$ & & & & & &
\end{tabular}

$\mathrm{T}$ test for simple regression with EVA as dependent variable shows $t$ score of 3.116 , larger that $\mathrm{t}$ table of 2.262, therefore regression coefficient is significant, and $\mathrm{H} 1$ is proven and accepted.

$\mathrm{T}$ test for simple regression with NOPAT as dependent variable shows sig. scores of 0.00 , lower that 0.05 , therefore $\mathrm{H} 1 \mathrm{a}$ is also proven and accepted. T test with WACC as dependent variable shows sig. score of 0.88, which are higher than 0.05, therefore $\mathrm{H} 1 \mathrm{~b}$ is rejected. $\mathrm{T}$ test for simple regression with IC as dependent variable shows sig. score of 0.00 , lower than 0.05 , therefore $\mathrm{H} 1 \mathrm{c}$ is proven and accepted.

$\mathrm{T}$ test for moderating regression with EVA as dependent variable shows sig. score above 0.05 , therefore $\mathrm{H} 2$ is not proven and rejected. $\mathrm{T}$ test for moderating regressions with each of EVA components shows sig. score of $0.243,0.412$, and 0.610 , each are larger than 0.05 , therefore $\mathrm{H} 2 \mathrm{a}, \mathrm{H} 2 \mathrm{~b}$, and $\mathrm{H} 2 \mathrm{c}$ are not proven and rejected.

\section{Table 6}

Simple Regression

\begin{tabular}{lccccc}
\hline \multirow{2}{*}{ Model } & \multicolumn{2}{c}{ Unstandardized Coefficients } & $\begin{array}{c}\text { Standardized } \\
\text { Coefficients }\end{array}$ & t & Beta \\
\cline { 2 - 5 } & B & Std. Error & & 49.745 & .000 \\
\hline (Constant) & 99567552.561 & 2001543.124 & & .002
\end{tabular}

a. Dependent Variable: NORM_EVA

Source: SPSS 26.0 (2021)

Above table shows the simple regression's equation which can be expressed as follows:

$$
Y=99567552.561+X 1(1490360.191)
$$

Where:

$\mathrm{Y}=$ firm performance, measured by EVA

(NORM_EVA)

X1 = ERM Implementation (NORM_ERM) 
Table 7

Moderating Regression

\begin{tabular}{|c|c|c|c|c|c|}
\hline \multirow[t]{2}{*}{ Model } & \multicolumn{2}{|c|}{ Unstandardized Coefficients } & \multirow{2}{*}{$\begin{array}{c}\begin{array}{c}\text { Standardized } \\
\text { Coefficients }\end{array} \\
\text { Beta }\end{array}$} & \multirow[t]{2}{*}{$\mathbf{t}$} & \multirow[t]{2}{*}{ Sig. } \\
\hline & $\mathbf{B}$ & Std. Error & & & \\
\hline (Constant) & 100933586.038 & 4167582.481 & & 24.219 & .000 \\
\hline NORM_ERMI & 495357.178 & 1004964.801 & .071 & .493 & .623 \\
\hline NORM_INDEKS_SR2 & -314567.368 & 1177181.490 & -.046 & -.267 & .790 \\
\hline NORM_SR_X_NORM_ERM & 257250.960 & 264755.107 & .224 & .972 & .332 \\
\hline
\end{tabular}

a. Dependent Variable: NORM_EVA

Source: SPSS 26.0 (2021)

Above table shows moderating regression equation, which can be expressed as follows:

$$
\begin{gathered}
Y=100933586.038+X 1(495357.178) \\
-X 2(314567.368)+X 1 X 2 \\
(257250.960)
\end{gathered}
$$

Where:

$\mathrm{Y}=$ Firm performance measured with

EVA (NORM_EVA)

$\mathrm{X} 1$ = implementation of ERM

(NORM_ERM)

$\mathrm{X} 2=$ disclosure of Sustainability

Reporting (NORM_INDEKS_SR)

$\mathrm{X} 1 \mathrm{X} 2=$ multiplication of $\mathrm{X} 1$ with $\mathrm{X} 2$

variable

The result of this study has proven that there is positive and significant effect of ERM towards business performance measured through EVA. We can then conclude, the higher the ERM implementation of a firm, the higher its business performance measured with EVA. Even so, the relatively small adjusted $\mathrm{r}$ square at $4.1 \%$ shows a small ERM's ability in explaining variability of business performance measured through EVA. Result of this study aligns with a number of past literatures on ERM and busines performance, such as Florio and Leoni (2017), Callahan and Soileau (2017), Lechner and Gatzert (2017), Wu et al. (2014), and more.

Moderating regression result shows that there is positive but insignificant impact of ERM towards business performance which are moderated by sustainability reporting. From this finding, we conclude that sustainability reporting can't confidently improves ERM impacts toward business performance.

The insignificant finding for the second hypothesis rises a number of question and assumptions on what cause the ineffectivity of sustainability reporting as moderating variable. Even if 
it plays a role as information media in firm's effort to alleviate corporate risk, the low number of publications and distributions in Indonesia compared to regular financial report can be a main reason sustainability reporting does not become the main consideration for stakeholder in decision making. Encouragement from regulator such as OJK (Otoritas Jasa Keuangan, No. 51/POJK.03/2017) for corporation to disclose sustainability reporting are also merely perceived as another compliance to fulfill, which led us to believe that awareness for corporate sustainability is still low.

From this study, we also conclude that main characteristics of investor in Indonesia's capital market tend to be purely rational. In making decision, the investor tend to disregard future prospects as implied in sustainability report. Costs as it appears in social and environmental efforts disclosed in sustainability report are perceived as harmful toward corporate. Based on this perception, firm with complete focus on purely economic profitability tend to appear as a more interesting investment option.
The inavailability of a universal measure for sustainability reporting yet, push a number of research within this topic to use subjective measurement. Difference between measurement can potentially create inconclusive study results.

\section{Conclusion, Limitation and Future Research}

\subsection{Conclusion}

According to result of our moderating regression analysis, we can conclude as follows:

1. ERM variables affect business performance measured through EVA, which is significant at $\alpha$ $5 \%$. ERM proved to be able to create shareholder value by increasing trade-off between risk and return. Effective ERM implementation can increase organization's ability in detecting potential risk and return from each projects in progress. With ERM implemented, management have a more comprehensive knowledge of industry's situation, and can take a valuemaximising strategic and operational decision, and 
potentially increase business performance.

a. ERM variable affects net operating profit after tax, which is a component of EVA. This effect is significant at $\alpha 5 \%$. From this test, we conclude that ERM implementation increase company's risk awareness, which can help better strategic decision making. This, along with monitoring and risk disclosure can decrease operational risk and push business to focus their resource on value creation activity, which can increase NOPAT.

b. ERM variable are proved to be not significant towards weighted average cost of capital at $\alpha$ of $5 \%$.

c. ERM are proved to be significant towards invested capital at $\alpha$ of $5 \%$. ERM are shown to increase trade-off between risk and return created by firm in the long run. Therefore, ERM implementation can increase firm's attractiveness toward investor through a more efficient and risk-aware capital resource management.

2. ERM variables proved to have no significant effect on EVA which are moderated by sustainability reporting. Sustainability reporting are expected to strengthen information user's knowledge on importance of ERM. Sustainability effort communicated can be associated with high awareness of risk, which could increase investor's and other stakeholder's trust. This can decrease cost of capital which also plays a role in improving financial performance measured through EVA. The addition of sustainability reporting as moderating variable does prove to be increasing the regression model's ability in explaining EVA variability as dependent variable, where adjusted $\mathrm{R}^{2}$ increase from $4.1 \%$ to $4.7 \%$. however, significance score higher than $\alpha 5 \%$ push us 
to conclude that sustainability reporting does not have a significant impact in moderating ERM relationships toward business performance.

a. ERM Variable are proved to be not significant toward NOPAT, which is moderated by sustainability reporting at $\alpha 5 \%$. Our conclusion for this are similar with main hypothesis.

b. ERM variable are proved to be not significant toward WACC, which is moderated by sustainability reporting.

c. ERM variable are proved to be not significant toward IC, which is moderated by sustainability reporting

During investment selection, a company isn't merely valued based from its financial return. We also need to consider company's ability in handling overall risks, since investor also wants to avoid potential loss from risks which can be detected and avoided with ERM. Modern portfolio theory is proven true in this research, where most investors want returns which are equal to potential risk.
Implementation of ERM help ensure that risks are disclosed and monitored objectively, which can ease the investment selection process.

A risk-averse investor tends to diversified their capitals into a firm with good risk management. ERM implementation can be a charming feature for this type of investor. Hence, from finance perspective, ERM implementation helps in improving business performance, by increasing invested capital. From operating perspective, ERM implementation clearly helps management in monitoring existing and potential risks in every business projects. Firm with a more comprehensive risk anticipation plans can better minimize their potential loss, which leads to increase in net profit.

\subsection{Research Limitation and Future Research}

Our research uses subjective measurement in measuring sustainability reporting variable. This can result in potential measurement difference from one sustainability research to another. Measurement for sustainability reporting variable are done using simple index, hence the value of variable only reflects 
compliance or completeness on sustainability requirements, and doesn't reflect the quality of sustainability reporting itself.

\section{REFERENCES}

Agustina, L., \& Baroroh, N. (2016). The relationship between Enterprise Risk Management (ERM) and firm value mediated through the financial performance. Review of Integrative Business and Economics Research, 5 (1), 128.

Asia Sustainability Reporting (Asia SR) Rating 2018. (2019, February 12). Retrieved from https://www.ncsrid.org/2019/02/12/sustainabilityreporting-awards-sra-2018/

Brundtland, G. H. (1987). Brundtland report. Our common future. Comissão Mundial.

Committee of Sponsoring Organizations of the Treadway Commission. (2004). The (COSO).(2004). Enterprise Risk Management-Integrated

Framework: Executive Summary.

Committee of Sponsoring Organizations of the Treadway Commission. (2017). COSO Enterprise Risk Management: Integrating with Strategy and Performancement. AICPA.

Daromes, F., Ng, S., \& Wijaya, N. (2020). Carbon Emissions
Disclosure as Mechanism to Increase Environmental Performance and Control of Idiosyncratic Risk: How They Impact Firm Value?. Indonesian Journal of Sustainability Accounting and Management, 4(2). doi:http://dx.doi.org/10.28992/ijsa $\underline{\text { m.v4i2.299 }}$

Dickinson, G. (2001). Enterprise risk management: Its origins and conceptual foundation. The Geneva Papers on Risk and Insurance. Issues and Practice, 26(3), 360-366.

Elkington, J. (1994). Triple bottom line revolution: reporting for the third millennium

Florio, C., \& Leoni, G. (2017). Enterprise risk management and firm performance: The Italian case. The British Accounting Review, 49(1), 56-74.

Freeman, R. E. (1984). Stakeholder management: framework and philosophy. Pitman, Mansfield, MA.

García-Zamora, E., Gonzalez-Benito, O., \& Munoz-Gallego, P. A. (2013). Organizational and environmental factors as moderators of the relationship between multidimensional innovation and performance. Innovation, 15(2), 224-244. 
Gordon, L. A., Loeb, M. P., \& Tseng, C. Y. (2009). Enterprise risk management and firm performance: A contingency perspective. Journal of accounting and public policy, 28(4), 301-327.

Gujarati， D. N. (2006). Dasar-dasar Ekonometrika jilid 1. Jakarta: Penerbit.

Hamudiana, A., \& Achmad, T. (2017). Pengaruh Tekanan Stakeholder Terhadap Transparansi Laporan Keberlanjutan PerusahaanPerusahaan di Indonesia. Diponegoro Journal of Accounting, 6(4), 226-236.

Hoyt, R. E., \& Liebenberg, A. P. (2011). The value of enterprise risk management. Journal of risk and insurance, 78(4), 795-822.

Karyawati, N. N., Yuniarta, G. A., \& Sujana, E. (2017). Pengaruh tingkat pengungkapan laporan keberlanjutan terhadap kinerja keuangan perusahaan. e-Journal S1 Ak Universitas Pendidikan Ganesha, 7(1), 1-10.

Keefe, T. B., King, R. D., \& Gaver, K. M. (1994). Audit fees, industry specialization, and compliance with GAAS reporting standards. Auditing, 13(2), 41.

Kiymaz, H. (2006). The impact of announced motives, financial distress, and industry affiliation on shareholders' wealth: Evidence from large sell-offs. Quarterly Journal of Business and Economics, 69-89.

Lai, F. W. (2011). A strategic framework for value enhancing enterprise risk management.

Lechner, P., \& Gatzert, N. (2018). Determinants and value of enterprise risk management: empirical evidence from Germany. The European Journal of Finance, 24(10), 867-887.

Markowitz, H. (1952). Modern portfolio theory. Journal of Finance, 7(11), 77-91.

McShane, M. K., Nair, A., \& Rustambekov, E. (2011). Does enterprise risk management increase firm value? Journal of Accounting, Auditing \& Finance, 26(4), 641-658.

Nocco, B. W., \& Stulz, R. M. (2006). Enterprise risk management: Theory and practice. Journal of applied corporate finance, 18(4), 820.

Richard, P. J., Devinney, T. M., Yip, G. S., \& Johnson, G. (2009). Measuring organizational performance: $\quad$ Towards methodological best practice. Journal of Management, 35(3), 718-804. 
Selvarajan, T. T., Ramamoorthy, N., Flood, P. C., Guthrie, J. P., MacCurtain, S., \& Liu, W. (2007). The role of human capital philosophy in promoting firm innovativeness and performance: Test of a causal model. The International Journal of Human Resource Management, 18(8), 1456-1470.

Shad, M. K., Lai, F. W., Fatt, C. L., Klemeš, J. J., \& Bokhari, A. (2019). Integrating sustainability reporting into enterprise risk management and its relationship with business performance: A conceptual framework. Journal of Cleaner production, 208, 415-425.

Tahir, I. M., \& Razali, A. R. (2011). The Relationship between enterprise risk management (ERM) and firm value: Evidence From Malaysian public companies. International journal of economics and management sciences, 1(2), 32-41.

Waweru, N., \& Kisaka, E. S. (2012, August). The effect of enterprise risk management implementation on the value of companies listed in the Nairobi stock exchange. AAA.

Wu, Y., Marshall, A., Chipulu, M., Li, Q., \& Ojiako, U. (2014). Enterprise risk management and firm value within China's insurance industry. Professional Accountant, 14(1), 1-10.

Zahid, M., \& Ghazali, Z. (2017). Corporate Sustainability Practices and Firm's Financial Performance: The Driving Force of Integrated Management System. Global Business \& Management Research, 9. 